\title{
PENGARUH FRAKSI AKTIF KULIT BATANG DYSOXYLUM ACUTANGULUM MIQ. (MELIACEAE) TERHADAP REPRODUKSI CROCIDOLOMIA PAVONANA (F.) (LEPIDOPTERA: PYRALIDAE)
}

\author{
Edy Syahputra $^{1}$, Djoko Prijono $^{2}$ dan Partomuan Simanjuntak ${ }^{3}$
}

\begin{abstract}
Effects of an active fraction of stem bark of Dysoxylum acutangulum Miq. (Meliaceae) on reproduction of Crocidolomia pavonana (F.) (Lepidoptera: Pyralidae). This study was conducted to determine the effect of an active fraction of Dysoxylum acutangulum stem bark on reproduction and longevity of the cabbage pest Crocidolomia pavonana. The feeding treatment with the test material was given to the second-instar larvae C. pavonana at concentrations of 2.54, 3.29 and $3.93 \mathrm{ppm}$ (equivalent to $\mathrm{LC}_{10}, \mathrm{LC}_{30}$ and $\mathrm{LC}_{50}$ ), then the emerging adults were observed for their fecundity, ovarial protein content and longevity. The treatment with the test material at $\mathrm{LC}_{50}$ shortened the lifespan of adult males and females C. pavonana by 2.9 and 1.6 days, respectively, compared with controls. The treatments at $\mathrm{LC}_{10}, \mathrm{LC}_{30}$ and $\mathrm{LC}_{50}$ decreased the fecundity of the adult females by 44.0, 64.7 and 58.1\%, respectively, compared with controls, and this effect could be associated with the decrease in protein content of ovaries of the females $(29.0,47.8$ and $42.8 \%$ decrease, respectively). Such treatments also delayed the maturity of ovaries of the females. Suppression of reproductive capacity of C. pavonana could contribute significantly to overall suppression of the pest population if the test material is used in the field.
\end{abstract}

Key words: Crocidolomia pavonana, Dysoxylum acutangulum, botanical insecticides, reproduction.

\section{PENDAHULUAN}

Crocidolomia pavonana (F.). (sin. Crocidolomia binotalis Zeller) merupakan hama oligofag yang menyerang berbagai tanaman sayuran Brassicaceae (Kalshoven, 1981). Kerusakan akibat serangan oleh larva C. pavonana dapat terjadi sejak tanaman muda hingga menjelang panen. Pada tanaman kubis, kehilangan hasil panen akibat serangan hama tersebut dapat mencapai $65,8 \%$ (Uhan, 1993). Besarnya kerusakan tanaman oleh suatu hama tergantung pada kelimpahan populasi hama tersebut di pertanaman. Sebagaimana populasi hama lainnya, fluktuasi populasi hama C. pavonana di lapangan dipengaruhi oleh berbagai faktor, di antaranya imigrasi, emigrasi, kematian dan kelahiran. Fluktuasi tingkat kelahiran suatu hama merupakan resultan dari berbagai faktor luar (lingkungan) dan faktor dalam seperti reproduksi dan perkawinan.

Pengembangan bahan pengendalian hama biasanya diarahkan untuk menghasilkan senyawa insektisida yang dapat mengakibatkan pengaruh langsung berupa kematian. Selain sifat letal, salah satu sifat penting lain insektisida ialah pengaruhnya terhadap reproduksi serangga. Perangsangan reproduksi merupakan salah satu dampak negatif insektisida yang dapat mengakibatkan resurjensi hama (Nemoto, 1993), sementara penekanan reproduksi dalam sinerginya dengan pengaruh kematian dapat mengakibatkan penurunan populasi hama yang lebih besar di lapangan. Karena itu, setiap bahan insektisida baru, baik alami maupun sintetik, perlu diuji pengaruhnya terhadap reproduksi serangga sasaran.

Salah satu sumber insektisida alami yang potensial adalah Dysoxylum acutangulum Miq. (Meliaceae). Ekstrak etanol kulit batang $D$. acutangulum (sebelumnya dilaporkan sebagai Aglaia angustifolia) memiliki toksisitas tinggi terhadap larva C. pavonana dengan $\mathrm{LC}_{50}$ 112,2 ppm (Prijono et al., 1999). Pada penelitian lebih lanjut, Aliyah et al. (2001) melaporkan bahwa LC $_{50}$ fraksi kloroform ekstrak metanol ranting $D$. acutangulum adalah 107,7 ppm dan bahan tanaman tersebut juga aktif dalam bentuk ekstrak airnya dengan $\mathrm{LC}_{50} 0,53 \%$. Salah satu fraksi aktif kulit batang $D$. acutangulum bersifat menghambat perkembangan serangga dengan tingkat aktivitas ( $\mathrm{LC}_{50}$ 6,6 ppm) yang sebanding dengan azadirakhtin (senyawa insektisida utama dalam tanaman mimba, Azadirachta indica) terhadap larva 
C. pavonana (Prijono et al., 2001). Namun, pengaruh bahan tersebut terhadap reproduksi serangga belum pernah dilaporkan.

Penelitian ini bertujuan untuk mengetahui pengaruh subletal $\left(\mathrm{LC}_{10}, \mathrm{LC}_{30}\right.$ dan $\left.\mathrm{LC}_{50}\right)$ salah satu fraksi aktif kulit batang $D$. acutangulum (Prijono et al., 2001) terhadap reproduksi dan lama hidup imago C. pavonana.

\section{METODE PENELITIAN}

\section{Serangga Uji}

Serangga uji, C. pavonana, diperbanyak di Laboratorium Fisiologi dan Toksikologi Serangga, Jurusan Hama dan Penyakit Tumbuhan, Institut Pertanian Bogor, dengan cara seperti yang diuraikan oleh Basana dan Prijono (1994). Larvanya diberi makan daun brokoli bebas pestisida dan imagonya diberi cairan madu 10\% yang diserapkan pada kapas.

\section{Penyiapan Fraksi Aktif $D$. acutangulum}

Fraksi aktif kulit batang D. acutangulum diperoleh dengan cara seperti yang telah diuraikan sebelumnya (Syahputra et al., 2001). Kulit batang D. acutangulum (asal hutan lindung Yan Lappa, Jasinga) dipotong kecil-kecil kemudian potongan kulit batang tersebut $(1,5 \mathrm{~kg})$ diekstrak $4 \mathrm{x}$ dengan etanol pada suhu 60-70 ${ }^{\circ} \mathrm{C}$ menggunakan pengekstrak soxhlet. Selanjutnya, pelarut dalam ekstrak diuapkan menggunakan rotavapor pada suhu $50{ }^{\circ} \mathrm{C}$ dan tekanan rendah. Ekstrak yang diperoleh (hasil 3,09\%) dipisahkan dalam campuran etil asetat - air, kemudian fase etil asetat diuapkan pelarutnya. Fraksi etil asetat yang diperoleh (hasil 2,39\%) dipisahkan fraksi aktifnya menggunakan kromatografi kolom gel silika dengan elusi bertingkat dengan campuran n-heksana etil asetat (50:1 sampai 1:1), kemudian etil asetat, dan terakhir etanol saja. Pemisahan fraksi aktif dipantau dengan uji hayati (Syahputra et al., 2001), yang menghasilkan empat fraksi aktif (dari total 33 fraksi), yaitu F-25, F-28, F-30, dan F-32 (hasil masing-masing 0,026\%, 0,087\%, 0,18\% dan 0,49\%). Fraksi-25 dipisahkan lebih lanjut menggunakan kolom gel silika dengan elusi bertingkat dengan campuran n-heksana etil asetat (2:1) dan terakhir etil asetat saja. Fraksi aktif yang diperoleh dari pemisahan terakhir (hasil 0,013\%) digunakan untuk percobaan.

\section{Metode Pengujian}

Pengaruh Fraksi Aktif D. acutangulum terhadap Keperidian dan Lama Hidup $C$. pavonana. Fraksi aktif D. acutangulum diuji pada konsentrasi 2,54, 3,29 dan 3,93 ppm, yang setara dengan $\mathrm{LC}_{10}, \mathrm{LC}_{30}$ dan $\mathrm{LC}_{50}$ fraksi tersebut terhadap larva instar 2 C. pavonana (Prijono et al., 2001). Perlakuan fraksi $D$. acutangulum diberikan pada larva instar 2 C. pavonana dengan metode residu pada daun (kontaminasi pakan), kemudian imago yang muncul digunakan untuk pengamatan reproduksi dan lama hidup.

Fraksi uji dilarutkan dalam campuran asetonmetanol (3:1) untuk memperoleh konsentrasi yang diinginkan. Larutan fraksi uji pada konsentrasi tertentu dioleskan pada setiap sisi bundaran daun brokoli (diameter $3 \mathrm{~cm}$ ) menggunakan sonde mikro (microsyringe) sebanyak $25 \mu \mathrm{l}$ per sisi. Setelah pelarutnya menguap, dua bundaran daun perlakuan dimasukkan dalam cawan petri (diameter $9 \mathrm{~cm}$ ) yang dialasi kertas serap, lalu 15 larva instar 2 C. pavonana dimasukkan ke dalam cawan tersebut. Larva kontrol diberi pakan daun yang hanya diolesi campuran aseton-metanol (3:1). Jumlah larva yang diberi perlakuan untuk setiap taraf konsentrasi uji dan kontrol diperhitungkan sedemikian rupa sehingga dapat diperoleh setidaknya 15 pasang imago.

Larva uji dibiarkan memakan daun perlakuan atau daun kontrol selama 2 hari, kemudian larva diberi makan daun tanpa perlakuan hingga larva mencapai instar 4. Setelah menjadi instar 4, larva dipindahkan ke wadah plastik yang lebih besar $(13 \mathrm{~cm} \mathrm{x} 11 \mathrm{~cm} \mathrm{x}$ $5,5 \mathrm{~cm}$ ), dan menjelang berkepompong ke dalam wadah tersebut diberi tanah steril. Imago yang muncul dipasangkan hingga diperoleh 15 pasang untuk setiap taraf konsentrasi uji dan kontrol. Setiap pasang imago dipelihara dalam kurungan plastik berventilasi (diameter $6,5 \mathrm{~cm}$, tinggi $30 \mathrm{~cm}$ ) dan diberi makan cairan madu $10 \%$ yang diserapkan pada kapas. Jumlah telur yang diletakkan dikumpulkan tiap hari dan dihitung. Imago dipelihara hingga mati dan lama hidupnya dicatat. Data keperidian imago betina per hari, produksi telur pada 5 hari pertama, serta lama hidup imago jantan dan betina diolah dengan sidik ragam yang dilanjutkan dengan uji LSD (Steel \& Torrie, 1980). 
Pengaruh Fraksi Aktif D. acutangulum terhadap Kandungan Protein Ovari Imago Betina C. pavonana. Pelaksanaan pengujian sama seperti pada pengujian sebelumnya. Imago normal yang muncul dari larva yang diberi perlakuan dan larva kontrol, baik jantan maupun betina, dipelihara secara berkelompok menurut perlakuannya dalam kurungan plastik berventilasi (diameter $20 \mathrm{~cm}$, tinggi $30 \mathrm{~cm}$ ) dan diberi makan cairan madu $10 \%$ yang diserapkan pada kapas.

Pengambilan ovari imago betina dilakukan setiap hari dari imago yang berumur 0 hari (baru muncul) hingga 11 hari. Ovari diambil dari dua imago betina C. pavonana dengan cara membedah abdomen serangga tersebut dalam genangan larutan Pringle (Pringle, 1938) di bawah mikroskop stereo. Ovari yang diperoleh dibersihkan dari badan lemak atau bagian tubuh lainnya, kemudian ovari tersebut dihancurkan dengan homogenizer gelas dalam $1 \mathrm{ml}$ akuabides pada suhu rendah (homogenizer gelas diletakkan dalam kotak pendingin yang berisi pecahan es). Hancuran ovari disentrifus pada kecepatan 10.000 rpm pada suhu $4{ }^{\circ} \mathrm{C}$ selama 30 menit. Supernatan hasil sentrifus dipindahkan ke dalam tabung sentrifus plastik, kemudian sambil digoyanggoyang ditambahkan larutan asam trikloroasetat sedikit demi sedikit untuk mengendapkan proteinnya. Larutan dan endapan yang terbentuk disentrifus kembali pada kecepatan $10.000 \mathrm{rpm}$ pada suhu $4{ }^{\circ} \mathrm{C}$ selama 45 menit. Supernatan hasil sentrifus terakhir dibuang dan endapan protein yang diperoleh disimpan di dalam freezer pada suhu $\pm-20{ }^{\circ} \mathrm{C}$ hingga siap dianalisis. Analisis protein dilakukan dengan metode Lowry (Kresze, 1988) dan pengukuran absorbansi larutan dilakukan pada $\lambda 500 \mathrm{~nm}$.

\section{HASIL DAN PEMBAHASAN}

\section{Pengaruh Fraksi Aktif D. acutangulum terhadap Keperidian dan Lama Hidup C. pavonana}

Perlakuan dengan fraksi aktif $D$. acutangulum pada konsentrasi 2,54, 3,29 dan 3,93 ppm mempersingkat lama hidup imago jantan C. pavonana masing-masing selama $0,9, \quad 3,0$ dan 2,9 hari dibandingkan kontrol, walaupun perbedaan nyata dengan kontrol hanya teramati pada perlakuan 3,29 ppm dan antar perlakuan konsentrasi tidak ada perbedaan nyata (Tabel 1). Pada betina, pemendekan lama hidup hanya teramati pada perlakuan konsentrasi 3,29 ppm (selama 1,6 hari dibandingkan kontrol), namun lama hidup imago betina pada perlakuan tersebut tidak berbeda nyata dengan kontrol maupun perlakuan lainnya. Data tersebut menunjukkan bahwa dalam hal lama hidup imago, individu jantan $C$. pavonana lebih terpengaruh daripada individu betinanya terhadap perlakuan fraksi aktif $D$. acutangulum pada saat fase larvanya. Hal ini kemungkinan karena individu betina memiliki kandungan lemak yang lebih tinggi dibandingkan individu jantan sehingga dapat menghalangi senyawa aktif yang akan mencapai bagian sasaran (Matsumura, 1985).

Tabel 1. Keperidian dan lama hidup imago C. pavonana yang muncul dari larva yang diberi perlakuan fraksi aktif kulit batang $D$. acutangulum saat instar 2

\begin{tabular}{ccccc}
\hline $\begin{array}{c}\text { Konsentrasi } \\
(\mathrm{ppm})\end{array}$ & \multicolumn{2}{c}{ Lama hidup (hari) } & $\begin{array}{c}\text { Jumlah telur/ } \\
\text { betina/hari }\end{array}$ & $\begin{array}{c}\text { Jumlah telur/betina } \\
\text { pada } 5 \text { hari pertama }^{1)}\end{array}$ \\
\cline { 2 - 3 } 0 (kontrol) & $14,07 \mathrm{a}$ & $12,13 \mathrm{ab}$ & $8,30 \mathrm{a}$ & $64,40 \mathrm{a}$ \\
$2,54(\mathrm{LC} 10)$ & $13,13 \mathrm{ab}$ & $13,87 \mathrm{a}$ & $4,65 \mathrm{ab}$ & $29,67 \mathrm{ab}$ \\
$3,29\left(\mathrm{LC}_{30}\right)$ & $11,07 \mathrm{~b}$ & $12,47 \mathrm{ab}$ & $2,93 \mathrm{~b}$ & $13,20 \mathrm{~b}$ \\
$3,93\left(\mathrm{LC}_{50}\right)$ & $11,13 \mathrm{ab}$ & $10,53 \mathrm{~b}$ & $3,48 \mathrm{ab}$ & $18,93 \mathrm{~b}$ \\
\hline
\end{tabular}

1) Rataan selajur yang diikuti huruf yang sama tidak berbeda nyata (uji BNT, $\alpha=0,05$; $\mathrm{n}=15$ ). 
Pengaruh fraksi aktif $D$. acutangulum tampak lebih nyata terhadap reproduksi daripada terhadap lama hidup. Keperidian per hari imago betina C. pavonana yang muncul dari larva yang diberi perlakuan bahan uji pada konsentrasi 2,54, 3,29 dan 3,93 ppm menurun masing-masing sebesar 44\%, 65\% dan 58\% dibandingkan kontrol. Penurunan produksi telur lebih mencolok bila yang dianalisis adalah produksi telur pada 5 hari pertama, yaitu ketiga perlakuan tersebut menurunkan produksi telur berturut-turut sebesar 54\%, 80\% dan 71\% dibandingkan kontrol (Tabel 1).

Produksi keturunan pada awal masa hidup imago sangat penting untuk menunjang kelangsungan generasi berikutnya karena keturunan yang dihasilkan lebih akhir akan memiliki risiko lebih besar untuk ditemukan musuh alaminya. Dengan demikian, perlakuan fraksi aktif $D$. acutangulum, selain mematikan larva yang diberi perlakuan (Prijono et al., 2001), juga dapat menekan populasi generasi berikutnya. Dengan kata lain, fraksi tersebut tidak perlu dikhawatirkan akan menimbulkan resurjensi.

Keperidian per hari maupun produksi telur 5 hari pertama pada perlakuan bahan uji 3,93 ppm $\left(\mathrm{LC}_{50}\right)$ lebih tinggi dibandingkan pada perlakuan 3,29 ppm $\left(\mathrm{LC}_{30}\right)$ (Tabel 1). Mungkin sebagian imago betina pada perlakuan 3,93 ppm lebih bugar dibandingkan pada perlakuan 3,29 ppm karena individu yang lebih peka akan mati oleh perlakuan $\mathrm{LC}_{50}$ tetapi masih dapat bertahan hidup pada perlakuan $\mathrm{LC}_{30}$.

Penurunan jumlah produksi telur diduga akibat gangguan oleh senyawa aktif $D$. acutangulum (dalam fraksi yang diuji) terhadap hormon ekdisteroid, hormon juvenil, dan beberapa hormon neuroendokrin yang berperan dalam mengendalikan proses vitelogenesis (Engelmann, 1984; Bownes, 1989; Nijhout, 1994; Cusson et al., 1994). Hal ini didukung oleh rendahnya kandungan protein ovari imago betina yang berkembang dari larva yang diberi perlakuan bahan uji. Pada masa praoviposisi $(0-2$ hari setelah kemunculan imago), kandungan protein ovari C. pavonana yang diberi perlakuan sangat rendah, sedangkan pada kontrol telah mencapai sekitar $40 \mu \mathrm{g} /$ ovari (Tabel 2). Pada masa puncak peneluran imago normal, yaitu $4-7$ hari setelah kemunculan imago (Prijono \& Hassan, 1992), perlakuan bahan uji pada konsentrasi 2,54, 3,29 dan 3,93 ppm menurunkan kandungan protein ovari masing-masing sebesar $29 \%, \quad 45 \%$ dan $50 \%$ dibandingkan kontrol.

Tabel 2. Kandungan protein ovari imago betina C. pavonana pada masa praoviposisi dan puncak peneluran (imago berasal dari larva yang diberi perlakuan fraksi aktif kulit batang D. acutangulum saat instar 2)

\begin{tabular}{|c|c|c|}
\hline \multirow[t]{2}{*}{ Konsentrasi (ppm) } & \multicolumn{2}{|c|}{$\begin{array}{c}\text { Rataan kandungan protein ( } \mu \text { g/ovari) } \\
\text { pada imago umur }{ }^{1)}\end{array}$} \\
\hline & $0-2$ hari & $4-7$ hari \\
\hline 0 (kontrol) & $39,71 \mathrm{a}$ & 238,66 a \\
\hline $2,54\left(\mathrm{LC}_{10}\right)$ & $0 \quad b$ & $170,54 \mathrm{ab}$ \\
\hline 3,29 (LC30) & $0 \quad b$ & $132,26 \mathrm{~b}$ \\
\hline 3,93 (LC50) & $2,09 \mathrm{~b}$ & $119,04 \quad b$ \\
\hline
\end{tabular}

1) Rataan selajur yang diikuti huruf yang sama tidak berbeda nyata (uji BNT, $\alpha=0,05$; $\mathrm{n}=15$ ). 


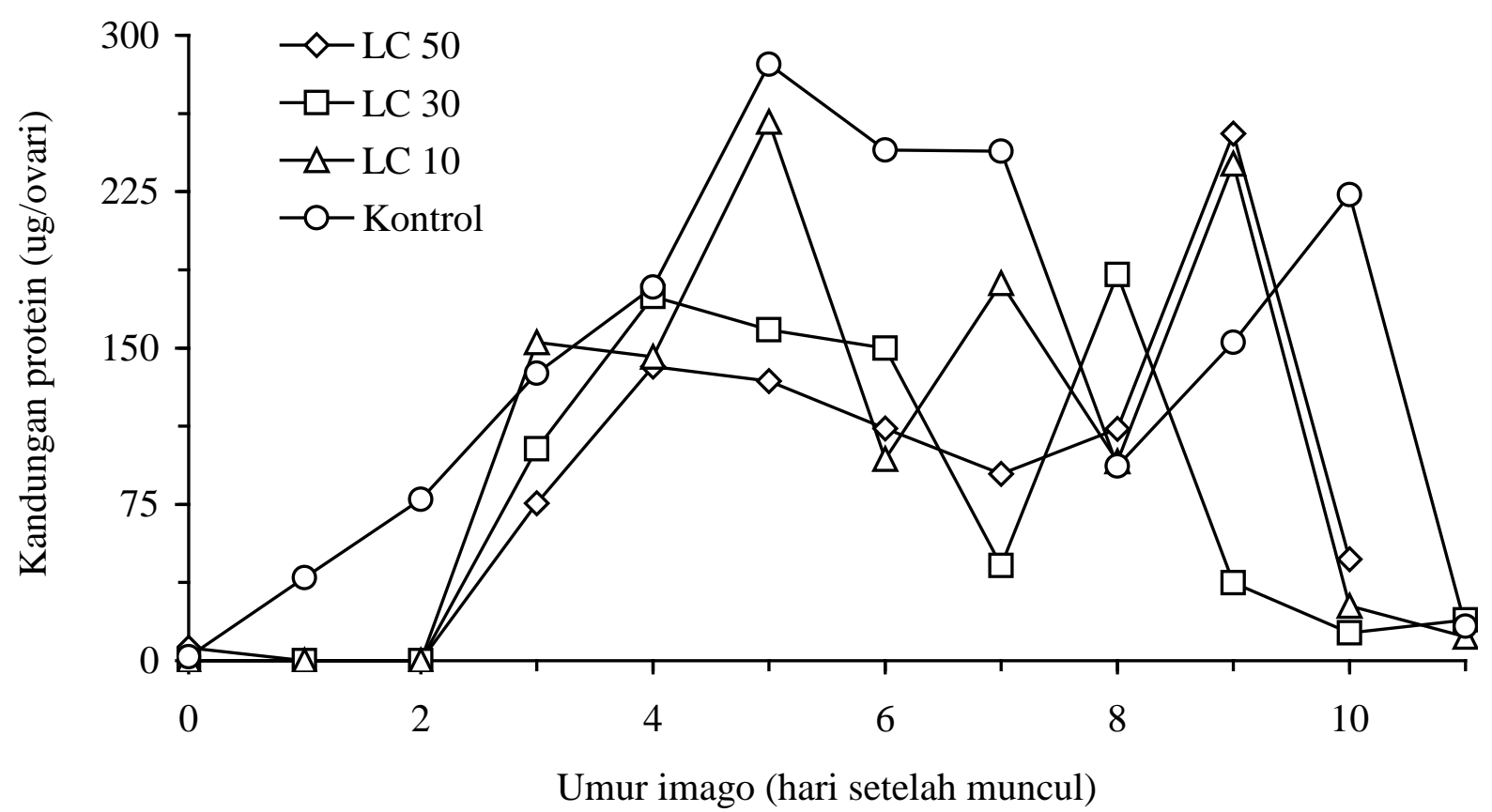

Gambar 1. Perkembangan harian kandungan protein ovari imago betina C. pavonana yang muncul dari larva yang diberi perlakuan fraksi aktif kulit batang D. acutangulum saat instar 2

Kandungan protein ovari imago C. pavonana yang berkembang dari larva yang diberi perlakuan bahan uji 2,54 ppm ( $\left.\mathrm{LC}_{10}\right)$ mencapai puncak pada hari kelima, sama dengan kandungan protein ovari imago kontrol (Gambar 1). Kandungan protein ovari imago pada perlakuan 3,29 ppm ( $\left.\mathrm{LC}_{30}\right)$ dan 3,93 ppm ( $\left.\mathrm{LC}_{50}\right)$ mencapai puncak pada hari kedelapan dan kesembilan. Dengan demikian kandungan protein ovari imago C. pavonana yang mendapat perlakuan fraksi aktif $D$. acutangulum pada $\mathrm{LC}_{30}$ dan $\mathrm{LC}_{50}$ tertunda mencapai puncak dibandingkan pada perlakuan kontrol dan $\mathrm{LC}_{10}$.

Prijono et al. (2001) melaporkan bahwa fraksi aktif $D$. acutangulum mengganggu proses ganti kulit metamorfosis pada larva C. pavonana, yang mencerminkan terjadinya gangguan terhadap fungsi hormon perkembangan serangga. Dalam proses ganti kulit dan metamorfosis serangga, sedikitnya ada tujuh jenis hormon yang terlibat, yaitu hormon protorasikotropik (PTTH), hormon juvenil, ekdison, hormon pemicu ekdisis, hormon eklosi, bursikon dan crustacean cardioactive peptide (CCAP) (Costron et al., 1995; Horodyski, 1996, Chapman, 1998). Rendahnya kandungan protein imago betina pada percobaan ini kemungkinan juga disebabkan oleh terganggunya sistem hormon yang mengatur sintesis atau penyerapan vitelogenin oleh ovari. Sintesis dan penyerapan vitelogenin pada banyak serangga dikendalikan oleh hormon juvenil atau ekdisteroid (Bownes, 1989; Cusson et al., 1994). Dengan demikian, senyawa aktif yang terdapat dalam sediaan D. acutangulum diduga mengganggu salah satu atau kedua jenis hormon tersebut (hormon juvenil atau ekdison).

Vitelogenesis pada serangga paling tidak diatur oleh dua mekanisme hormonal. Mekanisme pengaturan ini tergantung pada jenis serangganya. Pada Locusta, hormon juvenil bekerja merangsang vitelogenesis pada badan lemak. Sebaliknya pada Phormia, vitelogenesis dirangsang oleh ekdisteroid (Chapman, 1998). Rembold (1989) menunjukkan bahwa azadirakhtin dari mimba dapat mengganggu titer ekdisteroid dan hormon juvenil.

Tertundanya waktu pencapaian puncak kandungan protein ovari imago C. pavonana yang teramati pada percobaan ini selain dapat disebabkan karena terganggunya penyerapan vitelogenin oleh ovari, juga dapat disebabkan karena terganggunya 
perkembangan ovari akibat perlakuan dengan fraksi aktif $D$. acutangulum. Perkembangan ovari itu sendiri dipengaruhi oleh hormon. Pada Phormia, hormon juvenil merangsang perkembangan (kesiapan folikel) ovari untuk menerima vitelogenin (Chapman, 1998).

\section{SIMPULAN}

Perlakuan fraksi aktif kulit batang $D$. acutangulum pada konsentrasi subletal ( $\mathrm{LC}_{10}, \mathrm{LC}_{30}$

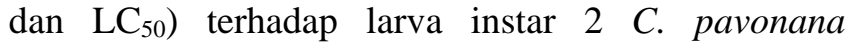
menurunkan keperidian dan menunda kematangan ovari imago betina yang muncul. Pengaruh ini dapat dikaitkan dengan penurunan kandungan protein ovari imago betina. Perlakuan pada $\mathrm{LC}_{50}$ juga mempersingkat lama hidup imago jantan maupun betina. Penekanan reproduksi dan pemendekan lama hidup imago akan memberikan sumbangan dalam penekanan populasi hama $C$. pavonana secara keseluruhan di lapangan.

\section{SANWACANA}

Ucapan terima kasih disampaikan kepada Pimpro RUT VI (1999/2000) atas bantuan dananya dan kepada Agus Sudrajat atas bantuan teknisnya.

\section{DAFTAR PUSTAKA}

Aliyah, A., D. Prijono \& Widodo. 2001. Aspek teknis dalam penyiapan insektisida botani dari tanaman Dysoxylum acutangulum Miq. untuk penggunaan di tingkat petani. p. 102-112. In: Prosiding Seminar Nasional III, Pengelolaan Serangga yang Bijaksana Menuju Optimasi Produksi. Bogor, 6 Nov. 2001.

Basana, I. R. \& D. Prijono. 1994. Insecticidal activity of aqueous extracts of four species of Annona (Annonaceae) against cabbage head caterpillar, Crocidolomia binotalis Zeller (Lepidoptera: Pyralidae). Bul. HPT 7: 50-60.

Bownes, M. 1989. The role of juvenil hormone, ecdysone and the ovary in the control of Drosophila vitellogenesis. J. Insect Physiol. 35: 409-413.

Chapman, R. F. 1998. The Insects: Structure and Function. 4th ed. Cambridge University Press, Cambridge.
Costron, B., K. Marquardt, U. Kaltenhauser \& H. W. Honegger. 1995. Bursicon, the cuticle sclerotizing hormone: comparison of its molecular mass in different insects. J. Insect Physiol. 41: 1045-1053.

Cusson, M., C. G. Yu, K. Carruthers, G. R. Wyatt, S. S. Tobe \& J. N. McNeil. 1994. Regulation of vitellogenin production in armyworm moth, Pseudaletia unipuncta. J. Insect Physiol. 40: 126136.

Engelmann, F. 1984. Vitellogenesis controlled by juvenile hormone. p. 259-270. In: Downer, R. G. H. \& H. Laufer (Eds.). Endocrinology of Insects. Alan R. Liss Inc., New York.

Horodyski, F. M. 1996. Neuroendocrine control of insect ecdysis by eclosion hormone. J. Insect Physiol. 42: 917-924.

Kalshoven, L. G. E. 1981. The Pests of Crops in Indonesia. Revised and translated by P. A. van der Laan. Jakarta: PT Ichtiar Baru - van Hoeve.

Kresze, G. B. 1988. Methods for protein determination. In: Bergmeyer, H. U., J. Bergmeyer \& M. Gral (Eds.). p 84-99. Methods of Enzymatic Analysis, Vol. II. 3rd. VCH, Weinheim.

Matsumura, F. 1985. Toxicology of Insecticides. 2nd ed. Plenum Press, New York.

Nemoto, H. 1993. Mechanism of resurgence of the diamondback moth, Plutella xylostella (L.) (Lepidoptera: Yponomeutidae). JARQ 27: 27-32.

Nijhout, H. F. 1994. Insect Hormones. Princeton University Press, Princeton.

Prijono, D. \& E. Hassan. 1992. Life cycle and demography of Crocidolomia binitalis Zeller (Lepidoptera: Pyralidae) on broccoli in laboratory. Indon. J. Trop. Agric. 4: 18-24.

Prijono, D., P. Simanjuntak P. \& B. Istiaji. 1999. Aktivitas insektisida ekstrak Aglaia spp. (Meliaceae) terhadap larva Crocidolomia binotalis Zeller (Lepidoptera: Pyralidae) (abstrak). p. 66. In: Panduan Seminar dan Kumpulan Abstrak Seminar Nasional Peranan Entomologi dalam Pengendalian 
Hama yang Ramah Lingkungan dan Ekonomis. Bogor, 16 Februari 1999.

Prijono, D., E. Syahputra, Sudarmo, B. W. Nugroho \& P. Simanjuntak. 2001. Aktivitas lima jenis insektisida alami terhadap ulat krop kubis Crocidolomia binotalis Zeller. p. 72-82. In: Prosiding Seminar Nasional III, Pengelolaan Serangga yang Bijaksana Menuju Optimasi Produksi. Bogor, 6 Nov 2001.

Pringle, J. W. S. 1938. Proprioception in insects. I. A new type of mechanical receptor from the palps of the cockroach. J. Exp. Biol. 15: 101-113.

Rembold, H. 1989. Azadirachtins, their structure and mode of action. p 150-163. In: Arnason, J. T., B. J. R. Philogene \& P. Morand (Eds.). Insecticides of Plant Origin. ACS, Washington DC.
Steel, R. G. D. \& J. H. Torrie. 1980. Principles and Procedures of Statistics: A Biometrical Approach. 2nd ed. McGraw-Hill Book Co., New York.

Syahputra, E., D. Prijono \& P. Simanjuntak. 2001. Aktivitas insektisida sediaan Dysoxylum acutangulum Miq. (Meliaceae) terhadap ulat kubis Crocidolomia binotalis Zeller. Makalah disajikan pada Seminar Nasional Pertanian Berkelanjutan, Pengelolaan Sumberdaya Alam Untuk Mencapai Produktivitas Optimum Berkelanjutan. Bandar Lampung, 26-27 Juni, 2001.

Uhan, T. S. 1993. Kehilangan hasil panen karena ulat krop kubis (Crocidolomia binotalis Zell) dan cara pengendaliannya. J. Hort. 3:22-26. 